\title{
An Approach to the Diagnosis of Acute Transverse Myelitis
}

\author{
Anu Jacob, M.D., ${ }^{1}$ and Brian G. Weinshenker, M.D., F.R.C.P.(C.) ${ }^{2}$
}

\section{ABSTRACT}

The differential diagnosis of acute inflammatory transverse myelitis (ATM) is broad. Therefore, physicians must be aware of the many potential etiologies for acute myelopathy, and should pursue an ordered, efficient, and cost-effective approach to the diagnosis based on the patient's clinical history, examination, and magnetic resonance imaging (MRI) findings. Clinical, immunological, and radiological findings of noncompressive myelopathies are reviewed, as are how these findings can be used to distinguish between demyelinating, infectious, other inflammatory, vascular, neoplastic, and paraneoplastic etiologies. We also review predictors of further episodes of ATM in patients with demyelinating disorders. We discuss the diagnostic clues and pitfalls of the not uncommon clinical scenario of a presumed "myelopathy with normal MRI." Finally, we suggest an algorithm for the diagnosis and management of acute myelopathies.

KEYWORDS: Myelitis, neuromyelitis optica, multiple sclerosis

\begin{abstract}
Acute transverse myelitis (ATM), an inflammatory myelitis, is one of the causes of acute transverse myelopathy. The three main categories in the differential diagnosis of ATM are demyelination, including multiple sclerosis (MS), neuromyelitis optica (NMO), and idiopathic transverse myelitis; infections such as herpes zoster and herpes simplex virus; and other inflammatory disorders such as systemic lupus erythematosus (SLE) and neurosarcoidosis. However, whether the cause of the acute myelopathy is inflammatory or not is not selfevident; therefore, the clinical and diagnostic workup for ATM requires that other causes of acute myelopathies be excluded.

When faced with a patient with an acute myelopathy, excluding an acute compressive cause is of utmost priority. A magnetic resonance imaging (MRI) scan is invaluable in this regard. Having excluded a compressive cause and having found an intrinsic spinal cord lesion on MRI, a detailed history and an examina-
\end{abstract}

tion followed by focused investigations are needed. In the following sections, clinical presentations of myelopathies are discussed followed by diagnostic categories of acute myelopathy. Only the classical presentations of the diseases are covered here. The predictors of relapses in demyelinating myelopathies are included, followed by an algorithm on diagnosis and treatment. Although we have used available literature and guidelines throughout, there may be instances where our personal clinical practice and experience have influenced our opinions and approach.

\section{CLINICAL PRESENTATION OF SPINAL CORD DISORDERS}

Spinal cord disorders are conventionally classified as "syndromes" due to the typical signs and symptoms produced because of the location of the lesion and specific tract involvement. The Brown-Séquard hemicord

\footnotetext{
${ }^{1}$ Division of Neurology, Walton Centre for Neurology and Neurosurgery, Liverpool, United Kingdom; ${ }^{2}$ Department of Neurology, Mayo Clinic College of Medicine, Rochester, Minnesota.

Address for correspondence and reprint requests: Brian G. Weinshenker, M.D., F.R.C.P.(C.), Department of Neurology, Mayo Clinic College of Medicine, 200 First Street SW, Rochester, MN 55905 (e-mail: weinb@mayo.edu).
}

Multiple Sclerosis and the Spectrum of CNS Inflammatory Demyelinating Diseases; Guest Editor, Claudia F. Lucchinetti, M.D. Semin Neurol 2008;28:105-120. Copyright (C) 2008 by Thieme Medical Publishers, Inc., 333 Seventh Avenue, New York, NY 10001, USA. Tel: $+1(212)$ 584-4662.

DOI 10.1055/s-2007-1019132. ISSN 0271-8235. 
Table 1 Clinical Presentation of Acute Spinal Cord Disorders

\begin{tabular}{|c|c|c|c|}
\hline Type of Lesion & Tracts Involved & Clinical Signs & Examples \\
\hline Complete & All tracts & $\begin{array}{l}\text { Pyramidal, sensory, and autonomic } \\
\text { dysfunction* below lesion }\end{array}$ & $\begin{array}{l}\text { Trauma or acute necrotizing } \\
\text { viral myelitis }\end{array}$ \\
\hline $\begin{array}{l}\text { Brown-Séquard } \\
\text { hemicord syndrome }\end{array}$ & $\begin{array}{l}\text { Ipsilateral corticospinal, } \\
\text { posterior columns; } \\
\text { contralateral spinothalamic }\end{array}$ & $\begin{array}{l}\text { Ipsilateral pyramidal weakness and } \\
\text { loss of posterior column function; } \\
\text { contralateral spinothalamic loss }\end{array}$ & $\begin{array}{l}\text { Multiple sclerosis, } \\
\text { compression }\end{array}$ \\
\hline $\begin{array}{l}\text { Anterior cord } \\
\text { syndrome }\end{array}$ & $\begin{array}{l}\text { Bilateral anterior horn cells } \\
\text { corticospinal tracts, } \\
\text { spinothalamic and autonomic }\end{array}$ & $\begin{array}{l}\text { Acute bilateral flaccid weakness, loss } \\
\text { of pain temperature and sphincter/ } \\
\text { autonomic dysfunction; preservation } \\
\text { of dorsal column modalities such } \\
\text { as joint position sense }\end{array}$ & $\begin{array}{l}\text { Anterior spinal artery } \\
\text { occlusion }\end{array}$ \\
\hline Posterior cord & Bilateral posterior columns & $\begin{array}{l}\text { Bilateral loss of light touch, vibration } \\
\text { and joint position }\end{array}$ & $\begin{array}{l}\text { B }_{12} \text { or copper deficiency } \\
\text { (usually chronic) }\end{array}$ \\
\hline Central & $\begin{array}{l}\text { Crossing spinothalamic, } \\
\text { corticospinal, and } \\
\text { autonomic fibers }\end{array}$ & $\begin{array}{l}\text { Dissociated sensory loss (loss of pain } \\
\text { and temperature with preserved } \\
\text { vibration and joint position); pyramidal } \\
\text { distribution weakness below lesion; } \\
\text { autonomic dysfunction below the lesion }\end{array}$ & $\begin{array}{l}\text { Syrinx, neuromyelitis } \\
\text { optica }\end{array}$ \\
\hline Conus medullaris & $\begin{array}{l}\text { Autonomic outflow and } \\
\text { sacral spinal cord } \\
\text { segments }\end{array}$ & $\begin{array}{l}\text { Early sphincter dysfunction, sacral } \\
\text { sensory loss and relatively mild motor } \\
\text { dysfunction }\end{array}$ & Post viral myelitis \\
\hline Cauda equina & $\begin{array}{l}\text { Spinal nerve roots of the } \\
\text { cauda equina }\end{array}$ & $\begin{array}{l}\text { Early often asymmetric flaccid weakness } \\
\text { of the lower limbs, sensory loss in } \\
\text { root distribution followed by autonomic } \\
\text { dysfunction }\end{array}$ & $\begin{array}{l}\text { Acute cytomegalovirus } \\
\text { polyradiculitis, } \\
\text { compression }\end{array}$ \\
\hline Tractopathies & Selective tract involvement & $\begin{array}{l}\text { Selective pyramidal, posterior column } \\
\text { involvement }\end{array}$ & $\begin{array}{l}\mathrm{B}_{12} \text { deficiency, paraneoplastic } \\
\text { myelopathy, multiple } \\
\text { sclerosis }\end{array}$ \\
\hline
\end{tabular}

${ }^{*}$ Autonomic dysfunction: bladder, bowel, and sexual.

syndrome is an example. Table 1 summarizes the clinical presentation of acute spinal cord disorders.

Myelopathies with selective tract involvement are characteristic of metabolic or degenerative myelopathies (which are usually chronic) rather than inflammatory or infectious disorders (e.g., corticospinal and posterior columns in $\mathrm{B}_{12}$ deficiency, adrenomyeloneuropathy, and Friedreich's ataxia). However, paraneoplastic myelopathies, which are rare, often produce tract-specific involvement and should be considered when investigations to exclude a metabolic or degenerative myelopathy are negative in acute symmetric "tractopathy." Occasionally, inflammatory demyelinating syndromes may present with a very selective tractopathy due to discrete lesions (e.g., the classical acute "sensory useless hand syndrome" with acute proprioceptive loss due to posterior column involvement in patients with $\mathrm{MS}$ ).

\section{NONCOMPRESSIVE CAUSES OF ACUTE MYELOPATHIES}

The five groups of disorders that present as acute myelopathy are: demyelination, infections, other inflam- matory disorders, vascular, and neoplastic and paraneoplastic. The first three are considered inflammatory disorders. Among these, demyelinating disorders are the most common. The initial task of the clinician is to determine which of these is most likely. In general, inflammatory disorders have an inflammatory cerebrospinal fluid (CSF) manifested by either pleocytosis, raised IgG index or both. Fig. 1 is an algorithm on the diagnosis and management of acute noncompressive myelopathies.

\section{Demyelinating Disorders}

Typically, the onset of neurological symptoms in myelitis due to demyelination occurs over days with sensory motor symptoms and bladder and bowel disturbances, although occasionally necrotizing demyelinating myelopathies, including NMO, may progress over hours. They usually occur in individuals who are otherwise in good health and may be preceded by a nonspecific viral illness. Table 2 provides the differential diagnoses of demyelinating myelopathies and their clinical-radiological features. 


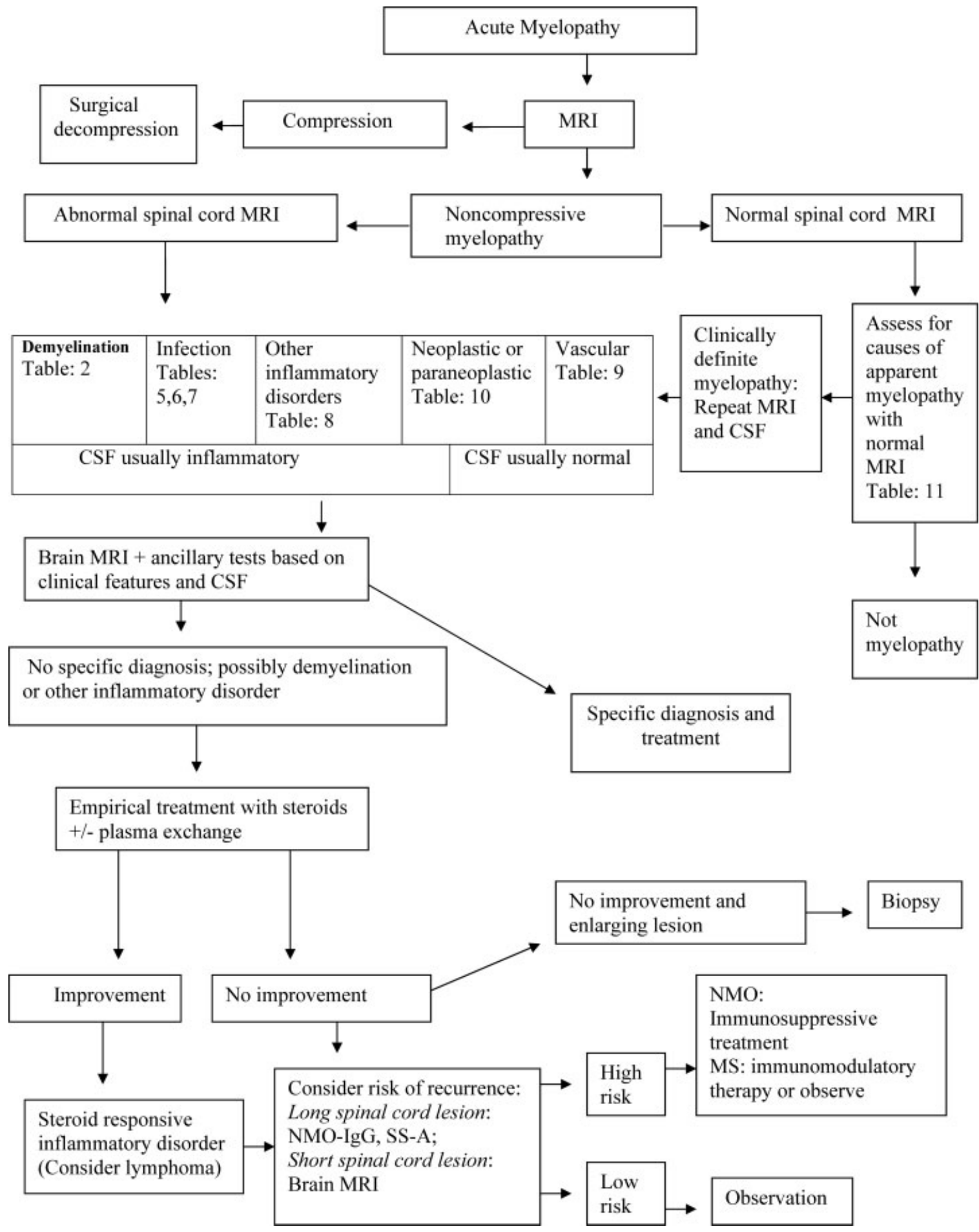

Figure 1 Diagnostic approach to acute myelopathy. MRI, magnetic resonance imaging; CSF, cerebrospinal fluid; NMO, neuromyelitis optica; MS, multiple sclerosis; IgG, immunoglobulin G; SS-A, Sjögren's syndrome antibody (anti-Ro).

\section{MULTIPLE SCLEROSIS}

In MS, lesions are usually small ( $<2$ vertebral segments in length) and peripheral, and therefore cause asymmetric symptoms and signs (Fig. 2). Lhermitte's sign (paresthesias spreading down the spine, often into the legs, on neck movement) is typical for a demyelinating lesion of the cervical posterior columns, but can be, although rarely, seen in other conditions that involve the same site. Other characteristic syndromes include isolated proprioceptive loss of an upper extremity ("sensory useless hand syndrome”), ${ }^{1}$ Brown-Séquard syndrome, or, more commonly, incomplete versions thereof. Early in 


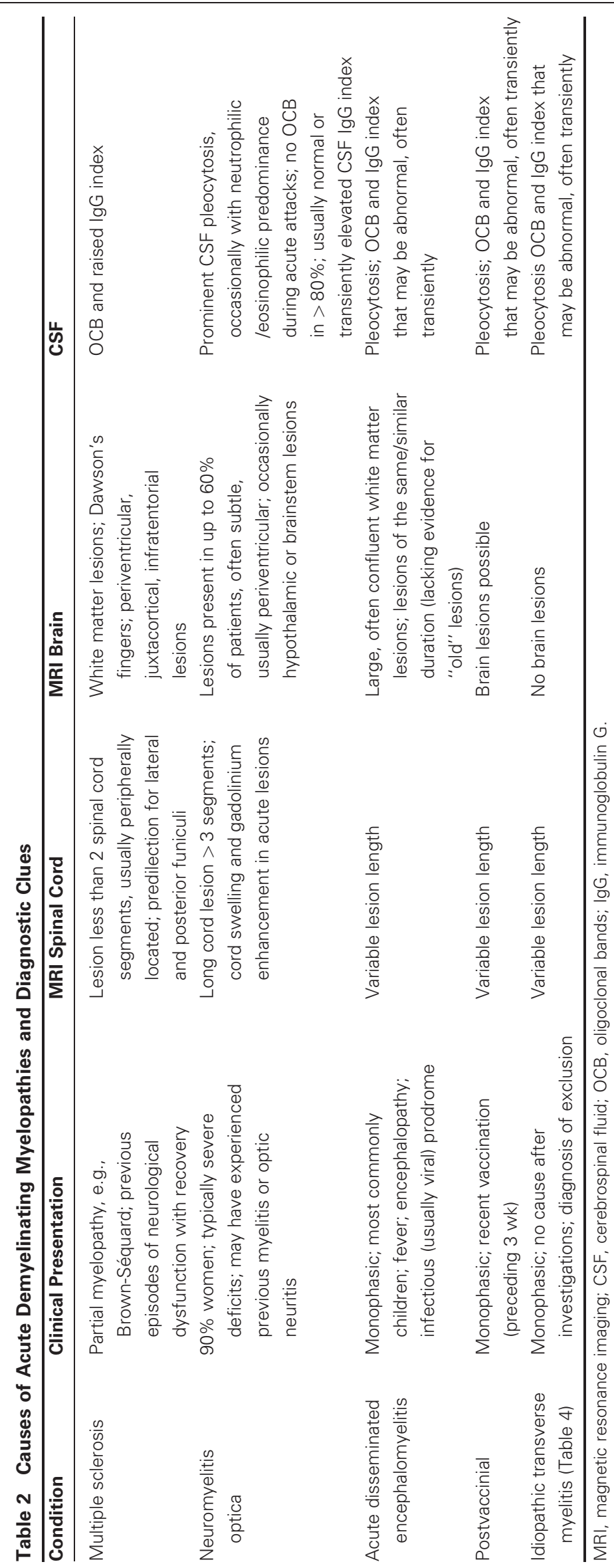



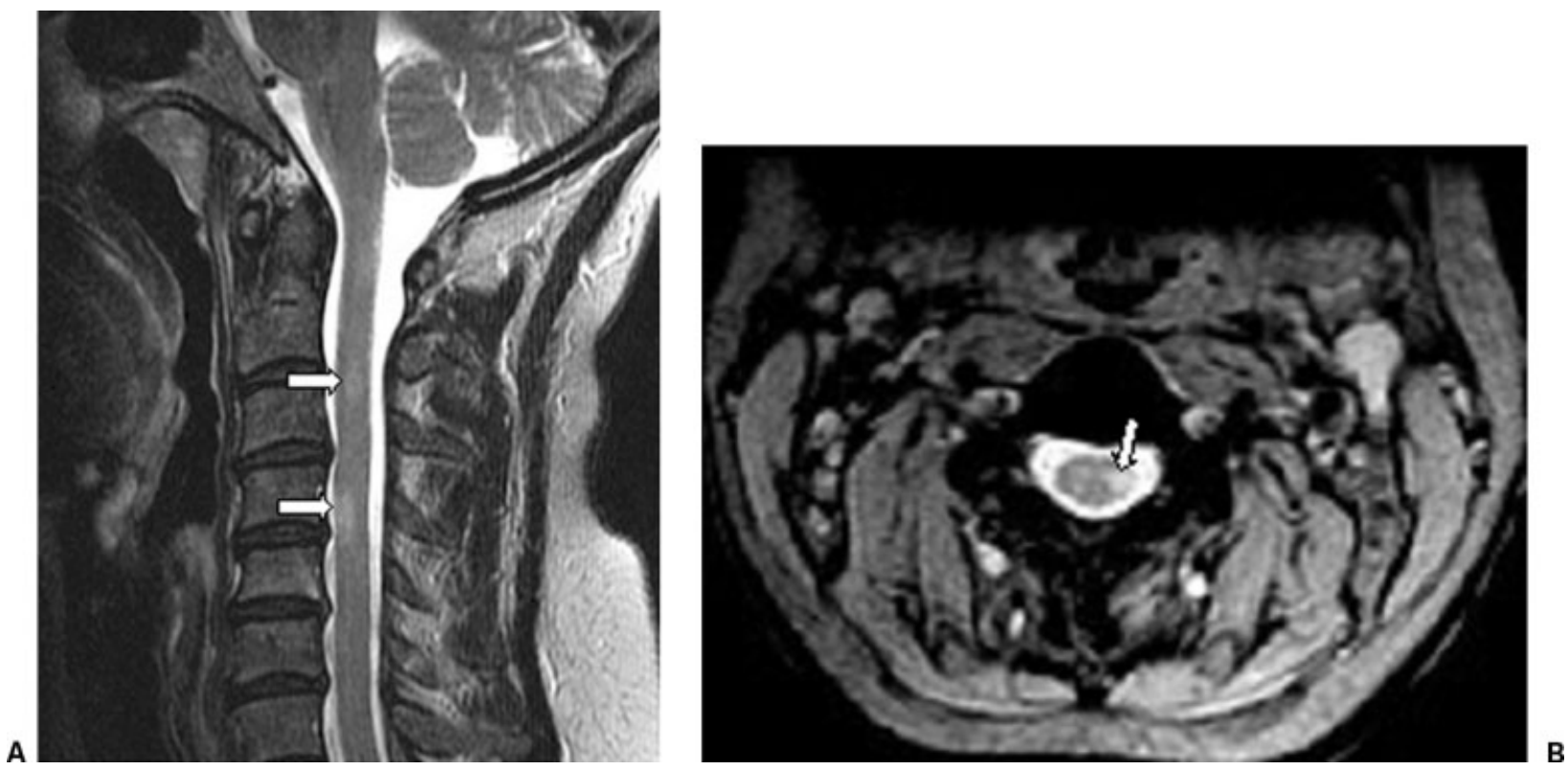

Figure 2 Cervical cord magnetic resonance imaging (MRI) from a 36-year-old woman with multiple sclerosis (MS). (A) Sagittal T2-weighted image shows discrete lesions without cord swelling. (B) Axial sections through the lower lesion show that the lesion is peripherally located within the cord.

the relapsing phase of MS, before the development of fixed gliotic scars, symptoms usually resolve in a few weeks to months. CSF oligoclonal bands (OCBs) are present in more than $90 \%$ of patients, and a raised immunoglobulin $(\mathrm{Ig}) \mathrm{G}$ index is seen in more than $60 \%$. Subclinical optic nerve involvement may be evident on visually evoked response testing. At the first occurrence of a partial myelitis, the presence of two or more brain lesions indicates an $88 \%$ chance of conversion to MS in the next 20 years. With a normal MRI, the risk is only $19 \% .^{2-4}$

\section{NEUROMYELITIS OPTICA}

Neuromyelitis optica is most commonly a relapsing demyelinating condition of the central nervous system (CNS) affecting predominantly the optic nerves and spinal cord. Table 3 lists the recently revised criteria for NMO. Lesions are centrally located and necrotic leading to more symmetric symptoms and signs, greater disability than seen in MS, and less complete recovery. The lesions in the cord are typically long (>3 vertebral segments) (Fig. 3). A history of severe optic neuritis should raise suspicion of NMO. NMO is relatively more common in Asian and African individuals, although the majority of patients with this condition in western countries are white. A variety of autoimmune conditions including SLE, Sjögren's syndrome, and thyroid autoimmune disorders may coexist with NMO. NMO-IgG is a recently identified serum antibody that is highly specific $(>90 \%)$ and sensitive $(>70 \%)$ for NMO. ${ }^{5}$ It is also present in NMO spectrum disorders, including limited forms of NMO such as relapsing optic neuritis and relapsing myelitis. When identified at the first attack, NMOIgG also predicts future episodes of myelitis or optic neuritis. In a prospective study, the risk of developing recurrent myelitis or new onset optic neuritis in patients with an isolated longitudinally extensive transverse myelitis was more than 50\% among those who were NMO-IgG seropositive, compared with $0 \%$ in those who were NMO-IgG seronegative. ${ }^{6}$ Brain MRI can be abnormal in NMO. Typically, lesions are periventricular, especially in regions of high concentration of aquaporin-4, the target antigen for the NMO-IgG. ${ }^{7}$

\section{ACUTE DISSEMINATED ENCEPHALOMYELTIS}

Acute disseminated encephalomyelitis (ADEM) is a monophasic disorder that affects the brain and occasionally the spinal cord. ${ }^{8}$ Often there is a history of preceding viral or other infectious illness. The brain and spinal cord

\section{Table 3 Diagnostic Criteria for Neuromyelitis Optica}

Optic neuritis

Acute myelitis

And at least two of three supportive criteria:

1. Contiguous spinal cord MRI lesion extends over 3 vertebral segments.

2. Brain MRI does not satisfy diagnostic criteria for multiple sclerosis.

3. NMO-lgG is seropositive.

MRI, magnetic resonance imaging; NMO, neuromyelitis optica; IgG, immunoglobulin G.

From Wingerchuk DM, Lennon VA, Pittock SJ, Lucchinetti CF, Weinshenker BG. Revised diagnostic criteria for neuromyelitis optica. Neurology 2006;66(10):1485-1489. 
A
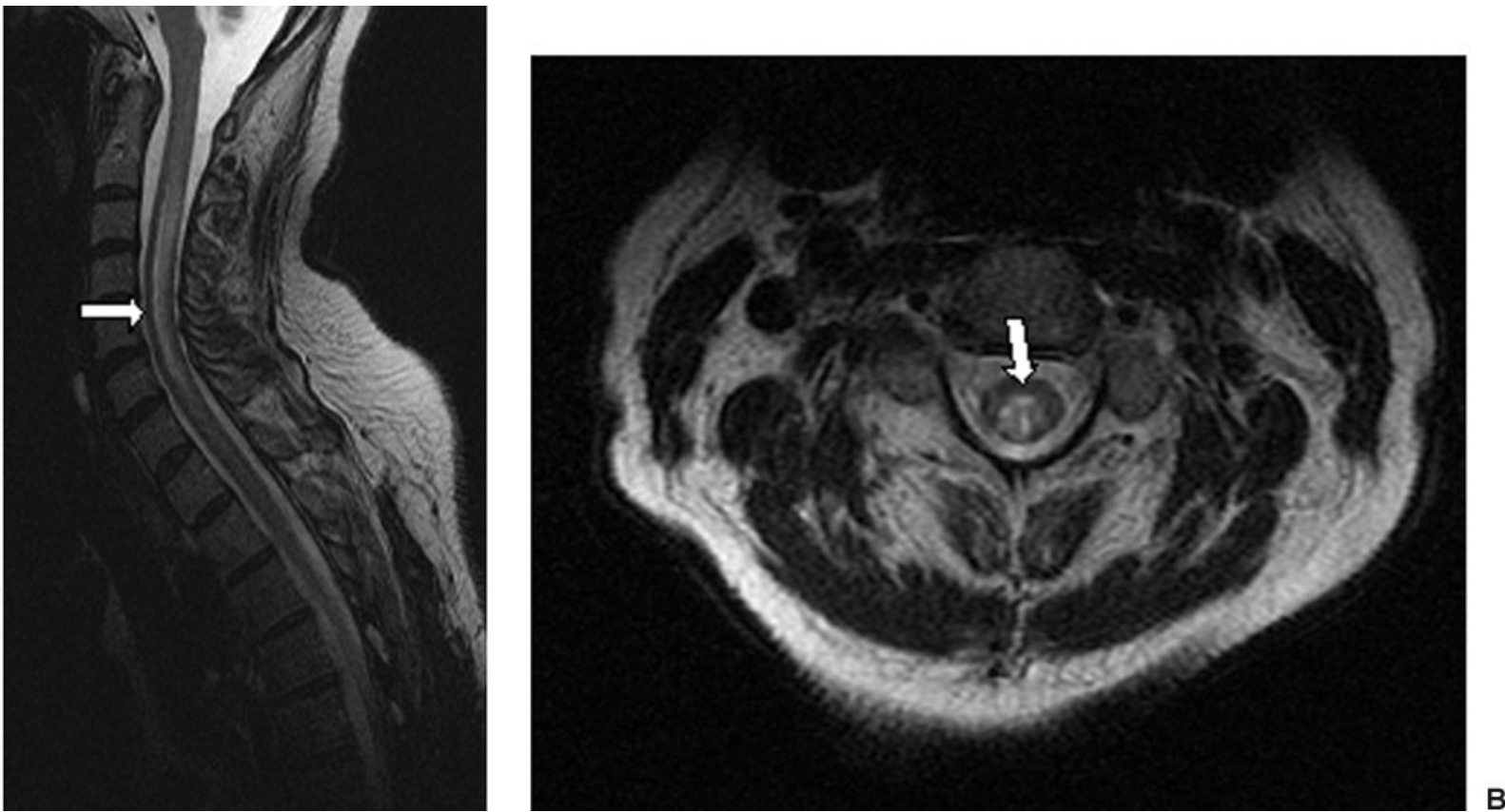

Figure 3 Cervical cord magnetic resonance imaging (MRI) from a 56-year-old woman with neuromyelitis optica (NMO). NMO-immunoglobulin (lg)G was positive. (A) Sagittal T2-weighted MRI scan shows a longitudinally extensive T2 hyperintense lesion. (B) Axial image shows that the lesion is central within the cord.

show demyelinating lesions that are generally of the same age, although gadolinium enhancement may not be seen in all, and, occasionally, not in any of the lesions. ADEM may evolve over the course of up to 3 months.
ADEM is more common in children, and is only reliably diagnosed in individuals who have concomitant encephalopathy. Follow-up of individuals with a clinical diagnosis of ADEM reveals that $\sim 25 \%$ of cases

\section{Table 4 Criteria for Idiopathic Acute Transverse Myelitis (modified from reference 17)}

\begin{tabular}{|c|c|}
\hline Inclusion Criteria & Exclusion Criteria \\
\hline $\begin{array}{l}\text { - Sensory, motor, or autonomic dysfunction } \\
\text { attributable to the spinal cord }\end{array}$ & $\begin{array}{l}\text { - History of previous radiation to the spine within } \\
\text { the past } 10 \text { years }\end{array}$ \\
\hline $\begin{array}{l}\text { - Bilateral signs and/or symptoms (though not } \\
\text { necessarily symmetric) }\end{array}$ & $\begin{array}{l}\text { - Clinical deficit consistent with thrombosis of the } \\
\text { anterior spinal artery }\end{array}$ \\
\hline - Clearly defined sensory level & $\begin{array}{l}\text { - Abnormal flow voids on the surface of the spinal cord } \\
\text { consistent with AVFs }\end{array}$ \\
\hline $\begin{array}{l}\text { - Exclusion of extra-axial compressive etiology } \\
\text { by neuroimaging (MRI, myelography; } \\
\text { CT of spine not adequate) }\end{array}$ & $\begin{array}{l}\text { - Serologic or clinical evidence of connective tissue } \\
\text { disease (sarcoidosis, Behçet's disease, Sjögren's } \\
\text { syndrome, SLE, mixed connective tissue disorder, etc.)* }\end{array}$ \\
\hline $\begin{array}{l}\text { - Inflammation within the spinal cord demonstrated } \\
\text { by CSF pleocytosis or elevated lgG index or } \\
\text { gadolinium enhancement }\end{array}$ & $\begin{array}{l}\text { - Clinical or laboratory evidence for syphilis, Lyme } \\
\text { disease, HIV, HTLV-1, Mycoplasma, other viral } \\
\text { infection (e.g., HSV- 1, HSV-2, VZV, EBV, CMV, } \\
\text { HHV-6, enterovirus)* }\end{array}$ \\
\hline $\begin{array}{l}\text { - If none of the inflammatory criteria is met at } \\
\text { symptom onset, repeat MRI and lumbar puncture } \\
\text { evaluation between } 2 \text { and } 7 \text { days following symptom onset }\end{array}$ & - Brain MRI abnormalities suggestive of $\mathrm{MS}^{*}$ \\
\hline $\begin{array}{l}\text { - Progression to nadir between } 4 \text { hours and } 21 \text { days } \\
\text { following the onset of symptoms (if patient awakens } \\
\text { with symptoms, symptoms must become more } \\
\text { pronounced from point of awakening) }\end{array}$ & - History of clinically apparent optic neuritis* \\
\hline
\end{tabular}

*Do not exclude disease-associated acute transverse myelitis.

AVFs, arteriovenous fistulas; MRI, magnetic resonance imaging; CT, computed tomography; CSF, cerebrospinal fluid; SLE, systemic lupus erythematosus; IgG, immunoglobulin G; HIV, human immunodeficiency virus; HTLV-1, human T-lymphotropic virus 1; HSV, herpes simplex virus; VZV, varicella zoster virus; EBV, Epstein-Barr virus; CMV, cytomegalovirus; HHV, human herpes virus. 
eventually meet clinical criteria for MS.

\section{POSTVACCINE MYELITIS}

An acute transverse myelitis occurring in the 3 weeks following a vaccination has been linked to an immunological reaction to the vaccine, such as smallpox or rabies. In recent years vaccines such as hepatitis $B$, typhoid, influenza, rubella, and tetanus have been implicated, ${ }^{9-14}$ but a causal relationship has not been established. Such cases may reflect chance occurrences of idiopathic transverse myelitis in patients who incidentally have had a vaccination.

\section{ACUTE IDIOPATHIC TRANSVERSE MYELITIS}

Inflammatory transverse myelitis (CSF inflammation with usual pleocytosis and occasionally elevated $\operatorname{IgG}$ index/OCBs) in the absence of a specific cause (such as MS, NMO, ADEM, connective tissue disease, etc.) is the most common cause of acute myelitis. ${ }^{15,16}$ Criteria have been proposed for this entity ${ }^{17}$ (Table 4). However, the idiopathic nature is a diagnosis of exclusion. The bimodal peaks in onset ages are 10 to 19 years and 30 to 39 years. A preceding nonspecific fever, nausea, or muscle pain, possibly indicating a prior viral infection, is common, although one or more of these symptoms may also precede attacks of MS and NMO. The lesion length varies from less than one segment to the entire cord. Many of these large series of patients were reported before NMO-IgG was identified, and it is possible that

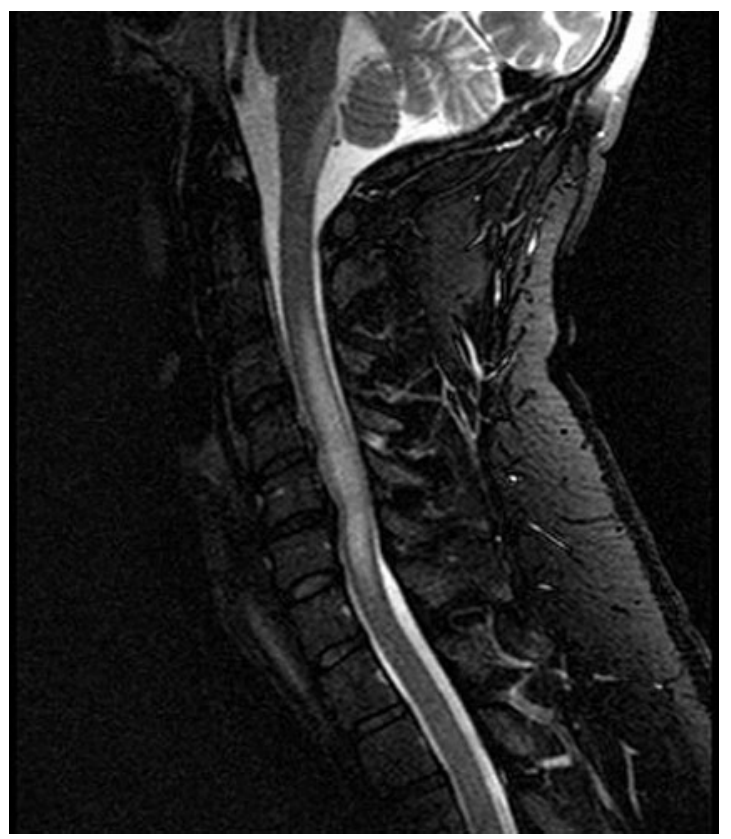

Figure 4 Sagittal T2-weighted magnetic resonance imaging (MRI) of the cervical cord in a 43-year-old man who developed herpes zoster in the upper limbs and simultaneously a longitudinally extensive cervical myelitis. (Image courtesy of Dr. Orhun Kantarci, Mayo Clinic, Rochester, MN.) many such patients may have an NMO spectrum disorder. The proportion of "idiopathic" inflammatory transverse myelitis is likely to decline with the increasing availability of newer autoimmune markers, imaging techniques, and microbiological tests capable of defining a specific etiology.

\section{Assessment for Recurrence Risk in Demyelinating Myelopathies}

After management of acute myelitis with steroids and/or plasma exchange, demyelinating myelopathies need to be evaluated for the risk of recurrence. The major decision point is whether a patient has complete or incomplete transverse myelitis (Fig. 1). Complete transverse myelitis usually has more or less symmetrical findings and involvement of motor, sensory, and sphincter function. Incomplete transverse myelitis usually has asymmetric findings that may involve a limited number of tracts and does not typically result in loss of all motor, sensory, and sphincter function. In general, complete transverse myelitis is associated with a long spinal cord lesion exceeding three vertebral segments in length, often central within the cord, and an incomplete transverse myelitis is associated with a short spinal cord lesion, typically one to two segments in length and peripheral. However, there are exceptions to this general rule.

\section{Patients with Complete Transverse Myelitis}

Complete transverse myelitis patients, in general, are at low risk for future development of MS. However, they could have recurrences consistent with relapsing myelitis or NMO. Two autoimmune markers that may predict recurrence are anti-Sjögren's syndrome antibody (SS-A) and NMO-IgG. ${ }^{18}$ NMO-IgG predicted each case of recurrence in a Mayo Clinic series,

Table 5 Clinical Indications Suspicious of an Infectious Myelopathy

\section{Fever}

Confusion

Meningismus

Rash

- Vesicular rash in the buccal mucosa and on the hands and feet in enterovirus 71

- Herpes zoster rash in dermatomal distribution

- Erythema chronicum migrans of Lyme disease (rarely presents as acute myelitis)

Concurrent systemic infection

Immunocompromised state

Recurrent genital infection

Lymphadenopathy

Residence in area endemic for parasitic infections 
Table 6 Causes of Acute Myelopathies Resulting from Infectious Agent

\begin{tabular}{|c|c|c|}
\hline & Specific Agen & \\
\hline \multirow[t]{18}{*}{ Viruses } & DNA Viruses & RNA viruses \\
\hline & Herpesviruses & Flaviviruses \\
\hline & Herpes simplex virus-2* & Dengue virus \\
\hline & Varicella-zoster virus* & Japanese encephalitis virus ${ }^{\dagger}$ \\
\hline & Cytomegalovirus* & St. Louis encephalitis virus \\
\hline & Human herpes viruses 6 and 7 & Tick-borne encephalitis virus \\
\hline & Epstein-Barr virus ${ }^{36^{*}}$ & West Nile virus ${ }^{\dagger}$ \\
\hline & & Orthomyxoviruses \\
\hline & & Influenza A virus \\
\hline & & Paramyxoviruses \\
\hline & & Measles virus \\
\hline & & Mumps virus \\
\hline & & Picornaviruses \\
\hline & & Coxsackieviruses $A$ and $\mathrm{B}^{\dagger}$ \\
\hline & & Echoviruses \\
\hline & & Enterovirus-70 and $-71^{\dagger}$ \\
\hline & & Hepatitis A, C ${ }^{37}$ \\
\hline & & Poliovirus types 1, 2, and $3^{\dagger}$ \\
\hline \multirow[t]{3}{*}{ Bacterial } & $\begin{array}{l}\text { Spinal cord abscess due to hematogenous spread } \\
\text { of systemic infection }\end{array}$ & \\
\hline & $\begin{array}{l}\text { Mycoplasma, Borrelia burgdorferi (Lyme), Treponema } \\
\text { pallidum (syphilis) }\end{array}$ & \\
\hline & Mycobacterium tuberculosis & \\
\hline Fungal & $\begin{array}{l}\text { Actinomyces, Blastomyces dermatitidis, Coccidioides, } \\
\text { Aspergillus }\end{array}$ & \\
\hline Parasites & $\begin{array}{c}\text { Neurocysticercosis, Schistosoma, Gnathostoma, } \\
\text { angiostrongylosis (eosinophilic myelitis) }\end{array}$ & \\
\hline
\end{tabular}

*Common causes.

†Can cause acute poliomyelitis-like syndrome due to preferential, rather than selective, destruction of anterior horn cells and other motor pathways.

Note: HTLV-1 (human T-lymphotropic virus 1) and HIV can cause a chronic myelitis without brain involvement.

whereas anti-SS-A did not. ${ }^{6}$ Thirty-eight percent of patients with a first episode of transverse myelitis were seropositive for NMO-IgG in a recent Mayo Clinic series; more than $50 \%$ of those followed for 1 year had recurrent myelitis or optic neuritis, whereas none of the seronegative patients experienced recurrence. ${ }^{6} \mathrm{We}$ currently advise testing for NMO- $\mathrm{IgG}$ in patients who have experienced a first episode of longitudinally extensive transverse myelitis, and instituting immunosuppressive therapy in those positive for NMO-IgG. We believe that monophasic inflammatory demyelinating transverse myelitis in patients seropositive for $\mathrm{NMO}-\mathrm{IgG}$ is a limited form of NMO with a high risk of relapse, or an NMO spectrum disorder, and should be managed accordingly.

\section{Patients with Incomplete Transverse Myelitis}

This group of patients is currently regarded as having a clinically isolated syndrome (CIS), which places them at risk for developing other symptoms that will lead to a definite diagnosis of MS. Cranial MRI is used to determine the degree of risk of MS. Those with lesions consistent with MS (two or more) are at high risk, currently estimated at $88 \%$ within 20 years. Those with a normal brain on MRI have a much lower risk, 19\% at 20 years. $^{2,4}$ Some experts advocate prophylactic treatment with disease-modifying therapy for highrisk patients. ${ }^{19}$ The prognosis for MS attacks may be much better than for NMO attacks, and some would argue that it would be worth waiting to determine if further disease activity occurs, given the highly variable and often favorable prognosis of MS. ${ }^{20}$ This is a major point of controversy regarding management of CIS. Other predictors of recurrence include CSF OCBs. ${ }^{21,22}$ MRI remains the single most potent predictor, although it is subject to problems of specificity of MRI-identified brain lesions for demyelinating disease.

\section{Acute Infectious Myelopathies}

Viral, bacterial, fungal, and parasitic agents can cause acute myelitis (Fig. 4). Patients are systemically ill with 
fever and meningismus. Prominent CSF inflammation (pleocytosis, often neutrophilic and raised protein concentration) must prompt investigation for a causative agent, especially a treatable one. This is in contrast to parainfectious or idiopathic inflammatory myelitis where patients have recovered from a recent infection, usually viral. Table 5 lists clinical clues to an infectious cause, Table 6 lists the infectious agents, and Table 7 provides diagnostic studies. However, in most cases of acute viral myelitis, a specific viral cause is never determined. ${ }^{23}$

\section{Myelopathies Associated with Other Inflammatory Disorders}

Connective tissue disorders and granulomatous disorders may present with acute or subacute myelitis. SLE, Sjögren's syndrome, scleroderma, mixed connective tissue disorder (MCTD), Behçet's disease, and sarcoidosis (Fig. 5) have all been associated with myelitis. ${ }^{24-26}$ However, it is rare for myelitis to be the presenting

\section{Table 7 Cerebrospinal Fluid Evaluation in Suspected} Infectious Myelitis

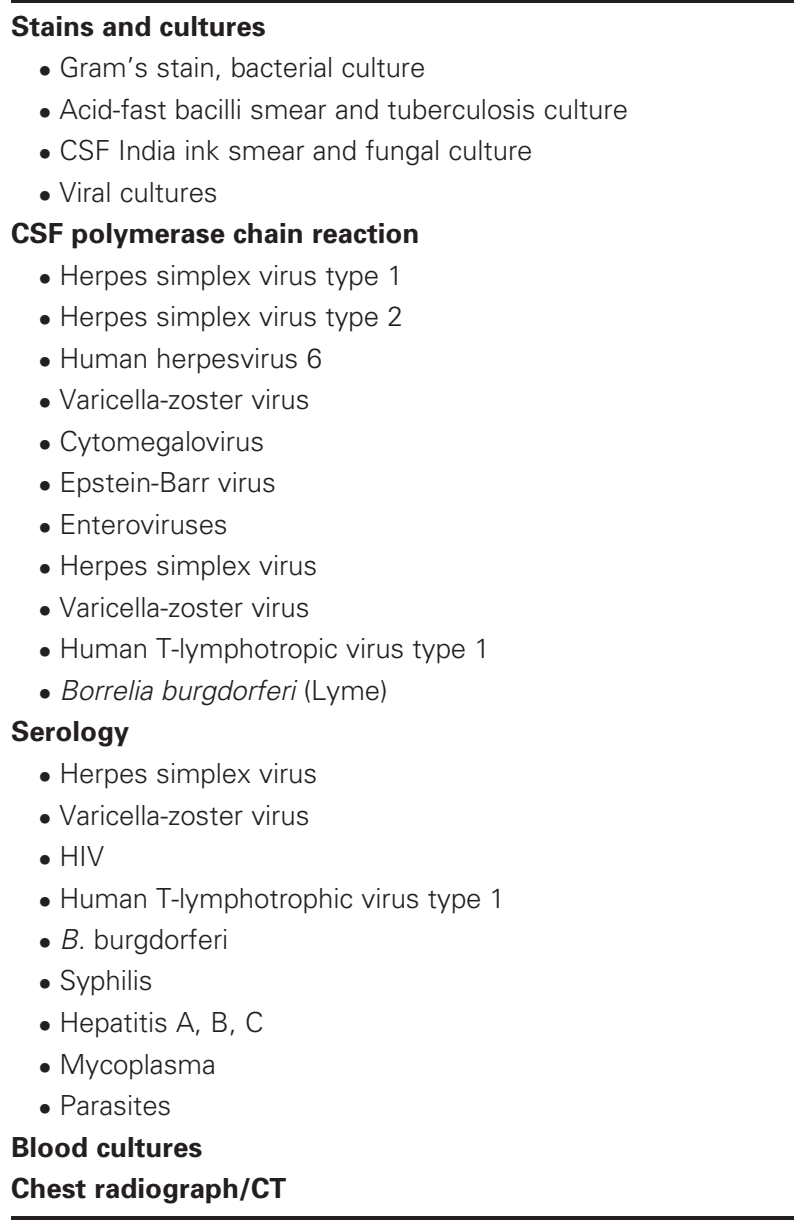

CSF, cerebrospinal fluid; HIV, human immunodeficiency virus; $\mathrm{CT}$, computed tomography. symptom. Almost invariably, classical systemic features, brain, or meningeal involvement, at least on MRI, will be present before development of myelitis. In general, established criteria for these disorders should be satisfied before the myelitis is attributed to these disorders. CSF is usually inflammatory, and MRI of the spinal cord may show enhancing lesions. The significance of an autoantibody (e.g., antinuclear antibody [ANA]) in isolation without consistent systemic clinical features is suspect. Table 8 lists the conditions that could cause acute inflammatory myelopathy and criteria needed to diagnose them. Recent evidence suggests that the presence of autoantibodies in patients with acute myelitis may suggest that the myelitis is an NMO spectrum disorder. This is because NMO-IgG is present in approximately half such cases, whereas it is absent in patients with connective tissue diseases, such as SLE and Sjögren's syndrome, who do not have a history of myelitis or optic neuritis.

\section{Vascular Disorders}

The arterial supply of the spinal cord consists of a single anterior spinal artery and two posterior spinal arteries (that course vertically over the surface of the cord) and their penetrating branches. ${ }^{27}$ Acute vascular occlusion can lead to spinal cord infarction mimicking myelitis (Fig. 6). Arterial occlusions are rare and develop acutely over minutes. However, arteriovenous fistulas (AVFs) usually progress slowly due to gradual ischemia resulting

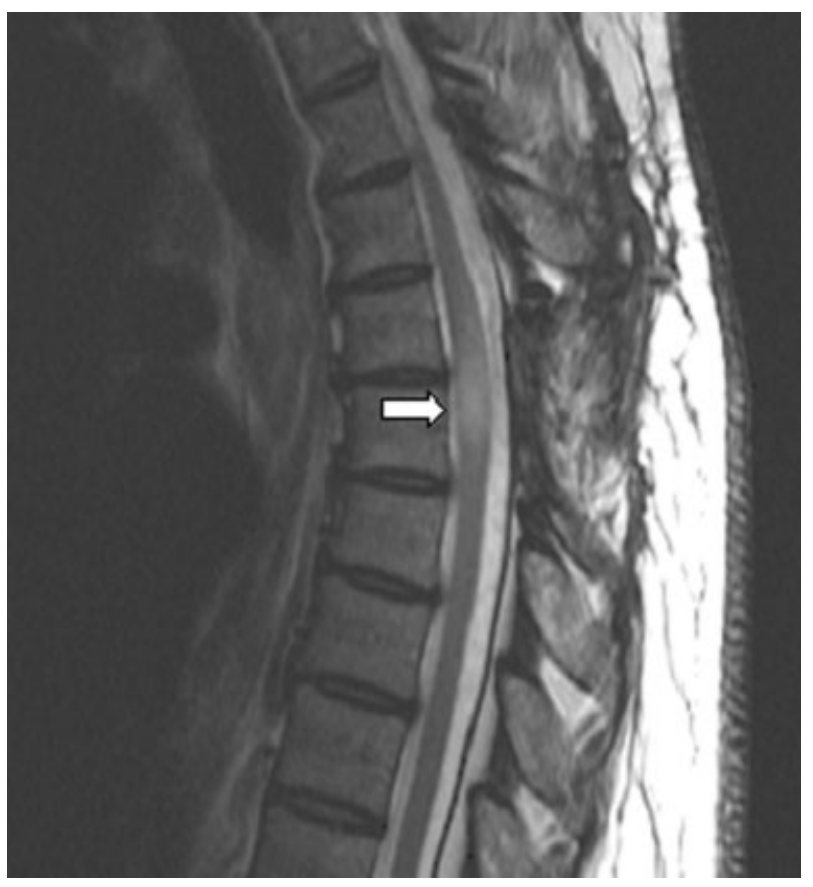

Figure 5 Sagittal T2-weighted magnetic resonance imaging (MRI) of the thoracic cord of a 45-year-old woman with sarcoidosis who presented with a subacute myelopathy. 
Table 8 Disorders that Could Cause Acute Inflammatory Myelopathy and Criteria to Diagnose Them

\begin{tabular}{|c|c|}
\hline Condition & Criteria \\
\hline SLE & $\begin{array}{l}\text { The } \mathbf{1 9 8 2} \text { revised criteria; } \mathbf{4} \text { of } \mathbf{1 1} \text { needed for diagnosis: }{ }^{38} \\
\text { 1. Malar rash } \\
\text { 2. Discoid rash } \\
\text { 3. Photosensitivity } \\
\text { 4. Oral ulcers } \\
\text { 5. Arthritis } \\
\text { 6. Serositis } \\
\text { 7. Renal disorder } \\
\text { 8. Neurologic disorder: (a) seizures or (b) psychosis (both not due to drugs or } \\
\text { metabolic abnormalities) } \\
\text { 9. Hematologic disorder } \\
\text { 10. Immunologic disorder (positive LE cell preparation/Anti-DNA/Anti-Sm/false-positive serologic } \\
\text { test for syphilis } \\
\text { 11. Antinuclear antibody }\end{array}$ \\
\hline $\begin{array}{l}\text { Primary Sjögren's } \\
\text { syndrome }\end{array}$ & $\begin{array}{l}\text { International consensus criteria; } \mathbf{4} \text { of } \mathbf{6} \text { any criteria or } \mathbf{3} \text { of } \mathbf{4} \text { objective criteria need to be present } \\
\text { for diagnosis: } \\
\text { 1. Dry eyes } \\
\text { 2. Dry mouth } \\
\text { 3. Objective evidence of dry eyes (at least one present): } \\
\quad \text { Schirmer test, Rose-Bengal, lacrimal gland biopsy } \\
\text { 4. Histopathology of minor salivary glands focal lymphocytic sialoadenitis } \\
\text { 5. Objective evidence of salivary-gland involvement (at least one present): } \\
\quad \text { Salivary-gland scintigraphy, parotid sialography, unstimulated whole sialometry (1.5 mL per } 15 \mathrm{~min} \text { ) } \\
\text { 6. Laboratory abnormality (at least one present): } \\
\quad \text { Anti-SS-A or anti-SS-B, ANA, IgM rheumatoid factor (anti-lgG FC) }\end{array}$ \\
\hline MCTD & $\begin{array}{l}\text { Diagnostic criteria: }{ }^{40} \\
\text { 1. Serological: High titer anti-U1RNP } \\
\text { 2. Clinical: Edema of hands/synovitis/myositis/Raynaud's phenomenon/acrosclerosis } \\
\text { 3. Serological criteria and at least three clinical criteria, including either synovitis or myositis required }\end{array}$ \\
\hline $\begin{array}{l}\text { Systemic sclerosis } \\
\text { (Scleroderma) }\end{array}$ & $\begin{array}{l}\text { ARA Preliminary classification criteria } \mathbf{1 9 8 0}:^{41} \\
\text { Proximal skin scleroderma or two of the following three criteria: } \\
\text { - Sclerodactyly (fingers or toes) } \\
\text { - Digital pitting scars/pulp loss } \\
\text { - Bibasilar pulmonary fibrosis }\end{array}$ \\
\hline Neurosarcoidosis & $\begin{array}{l}\text { Proposed criteria for diagnosis: } \\
\text { Definite: Clinical presentation suggestive of neurosarcoidosis with exclusion of other possible diagnoses } \\
\text { and the presence of nervous system histology } \\
\text { Probable: Clinical syndrome suggestive of neurosarcoidosis with: } \\
\text { - Laboratory support for CNS inflammation (elevated levels of CSF protein and/or cells, the presence of } \\
\text { oligoclonal bands and/or MRI evidence compatible with neurosarcoidosis) } \\
\text { - Exclusion of alternative diagnoses } \\
\text { - Evidence for systemic sarcoidosis (either through positive histology, including Kveim test, and/or at } \\
\text { least two indirect indicators from Gallium scan, chest imaging, elevated serum ACE) } \\
\text { Possible: Clinical presentation suggestive of neurosarcoidosis with exclusion of alternative diagnoses } \\
\text { where the above criteria are not met }\end{array}$ \\
\hline Behçet's Disease & $\begin{array}{l}\text { International Study Group for Behçet's Disease; } 1990 \text { criteria: }{ }^{42} \\
\text { Recurrent oral ulceration should occur at least three times in } 1 \mathrm{y} \text {, accompanied by any two of the following: } \\
\text { 1. Recurrent genital ulcers } \\
\text { 2. Anterior or posterior uveitis or retinal vasculitis } \\
\text { 3. Skin lesions (erythema nodosum, acneiform nodules, pseudofolliculitis, and papular lesions) } \\
\text { 4. Positive pathergy test }\end{array}$ \\
\hline
\end{tabular}

SLE, systemic lupus erythematosus; LE, lupus erythematosus; SS-A, Sjögren's syndrome antibody A (anti-Ro); SS-B, Sjögren's syndrome antibody B (anti-La); ANA, antinuclear antibody; Ig, immunoglobulin; Fc, fragment, crystallizable (of immunoglobulin); MCTD, mixed connective tissue disorder; ARA, American Rheumatism Association; CNS, central nervous system; CSF, cerebrospinal fluid; MRI, magnetic resonance imaging; ACE, angiotensin-converting enzyme. 


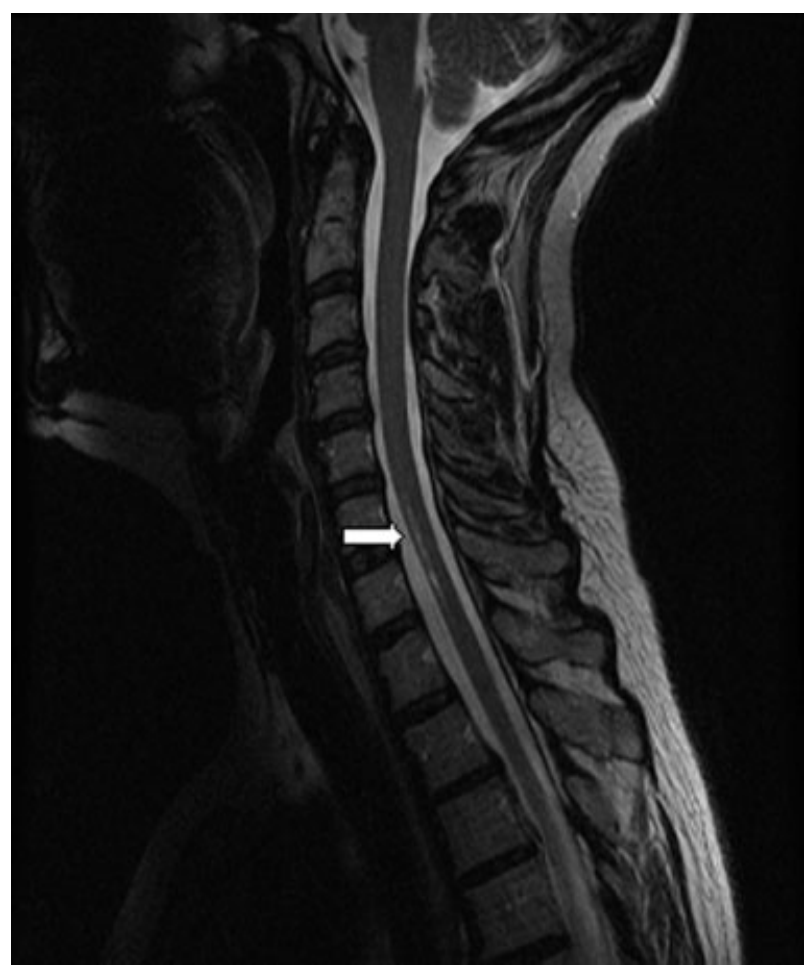

Figure 6 Sagittal T2-weighted cervical magnetic resonance imaging (MRI) of a 49-year-old woman who developed acute paraparesis and a thoracic sensory level to pain following heavy physical exertion. Arrow points to the linear lesion in the anterior cord-presumed anterior spinal artery occlusion. (Image courtesy of Mark Keegan, Mayo Clinic, Rochester $\mathrm{MN}$.)

from venous congestion. Sudden decompensation of myelopathy caused by AVFs or bleeding into vascular malformations may also mimic myelitis (Fig. 7). CSF is usually normal, although spinal AVF can lead to elevated
CSF protein concentration without pleocytosis. Causes of acute vascular myelopathies and diagnostic clues are listed in Table 9.

\section{Neoplasia and Myelopathy}

Intramedullary metastatic disease and intradural extramedullary compressive tumors (neurofibromas and meningiomas) are common causes of acute or acuteon-chronic myelopathy. Primary intramedullary cord tumors (ependymomas, astrocytomas, hemangioblastomas) or metastatic intramedullary tumors usually present over weeks. This is not a difficult diagnosis when there is an enhancing heterogenous lesion on MRI, especially with known systemic cancer. However, certain situations may cause diagnostic dilemmas.

\section{ACUTE PRESENTATIONS OF SPINAL TUMORS}

Hemorrhage or infarction of tumors resulting in acute swelling can mimic myelitis. Intramedullary cord lymphomas may respond symptomatically and radiologically to corticosteroids, which can further confuse the diagnosis. If serial imaging, CSF studies, and a search for a primary neoplasm are inconclusive, cord biopsy may be necessary. OCBs in CSF may be seen with tumors, but persistence of the bands is unusual. ${ }^{28}$ Persisting gadolinium enhancement months after treatment of an acute myelitis should alert physicians to a potential neoplasm. $^{28}$

\section{RADIATION-ASSOCIATED MYELOPATHY}

Radiation-induced myelopathies are usually slowly progressive but may occur up to 15 years after the end of radiation treatment, which may obscure the role of radiation therapy in causing the myelopathy. Early in

\section{A}
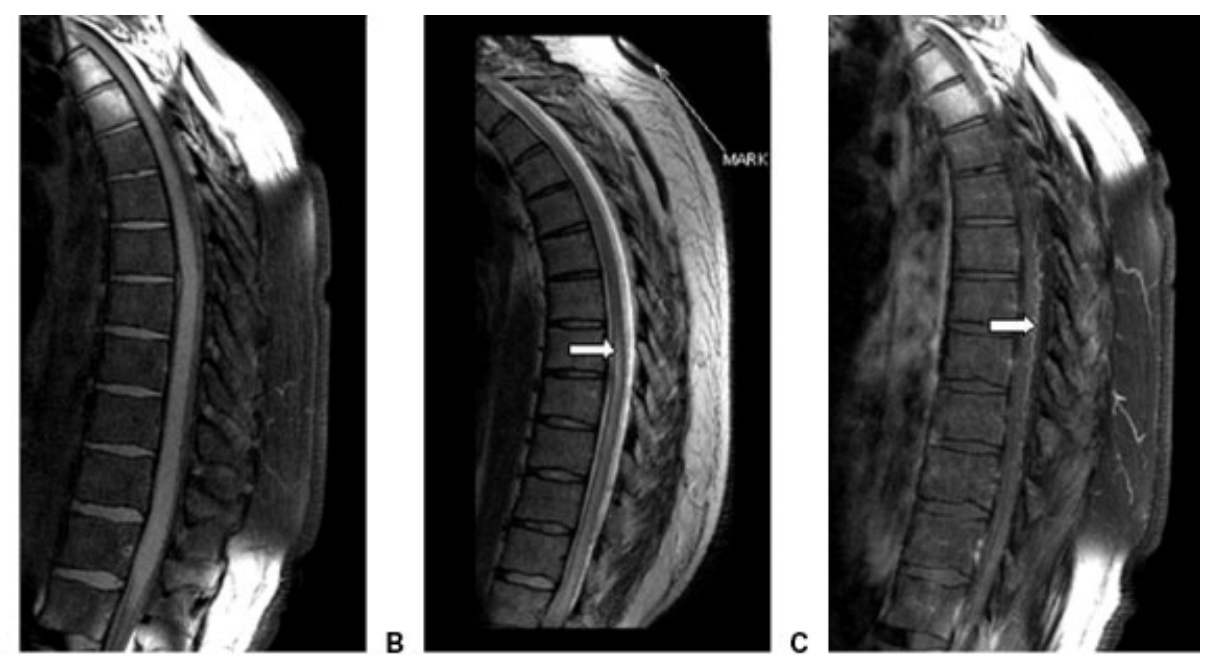

Figure 7 A 49-year-old man who presented with acute myelopathy. (A) T1-weighted image shows no definite abnormality. (B) T2-weighted image shows hyperintense longitudinally extensive lesion. (C) Gadolinium-enhanced T1-weighted image reveals dilated blood vessels on the surface of the cord. 
Table 9 Causes of Acute Vascular Myelopathies and Diagnostic Clues 27,43,44

\begin{tabular}{|c|c|c|}
\hline Condition & Clinical Presentation & MRI Spinal Cord \\
\hline $\begin{array}{l}\text { Anterior spinal artery } \\
\text { occlusion }^{27} \text { (spinal } \\
\text { radicular artery } \\
\text { occlusion is clinically } \\
\text { indistinguishable) }\end{array}$ & $\begin{array}{l}\text { Anterior cord syndrome especially in } \\
\text { the following settings: } \\
\text { - Aortic surgery } \\
\text { - Spinal angiography } \\
\text { - Vasculitis } \\
\text { - Embolic source (e.g., cardiac; cholesterol) } \\
\text { - Aortic/vertebral dissection } \\
\text { - Hypotension } \\
\text { - Prothrombotic states (e.g., sickle cell; protein } \\
\text { C or S deficiency; activated protein C } \\
\text { resistance/Factor V Leiden; antiphospholipid } \\
\text { syndromes) }\end{array}$ & $\begin{array}{l}\text { Elongated "pencil-like" lesion in the } \\
\text { anterior cord }\end{array}$ \\
\hline $\begin{array}{l}\text { Posterior spinal } \\
\text { artery occlusion }\end{array}$ & $\begin{array}{l}\text { Posterior column dysfunction } \\
\text { • Etiology as above }\end{array}$ & Triangular lesion in posterior cord \\
\hline $\begin{array}{l}\text { Sulcocommissural } \\
\text { artery }^{27}\end{array}$ & $\begin{array}{l}\text { Brown Séquard syndrome } \\
\text { - Etiology as above }\end{array}$ & Lateral cord lesion \\
\hline $\begin{array}{l}\text { Arteriovenous } \\
\text { fistulas }\end{array}$ & $\begin{array}{l}\text { - Stepwise progressive or recurrent } \\
\text { episodes of weakness related } \\
\text { to upright posture or walking, } \\
\text { accompanied by upper motor } \\
\text { neuron or lower motor } \\
\text { neuron syndrome or both } \\
\text { - Due to ischemia or congestion }\end{array}$ & $\begin{array}{l}\text { Long spinal cord lesion often extending into } \\
\text { the conus on T2 images; tortuous vessels } \\
\text { seen on the surface of the cord; if highly } \\
\text { suspected, despite normal MRI proceed } \\
\text { to spinal angiogram }\end{array}$ \\
\hline Hematomyelia & $\begin{array}{l}\text { - Bleeding diathesis (coagulation/platelet) } \\
\text { - Cavernomas } \\
\text { - Arteriovenous malformations of the cord } \\
\text { - Osler-Rendu-Weber syndrome (hereditary } \\
\text { hemorrhagic telangiectasia) }\end{array}$ & $\begin{array}{l}\text { Appearance of blood products (exact } \\
\text { appearance depends on stage) } \\
\text { Flow voids in the cord }\end{array}$ \\
\hline $\begin{array}{l}\text { Fibrocartilaginous } \\
\text { disc embolism } \\
45\end{array}$ & $\begin{array}{l}\text { - Back pain and history of physical exertion } \\
\text { - Features of anterior spinal artery occlusion }\end{array}$ & $\begin{array}{l}\text { Loss of vertical intervertebral disc height } \\
\text { and T2 signal abnormality in corresponding } \\
\text { level cord; microfractures of the vertebral } \\
\text { endplates }\end{array}$ \\
\hline
\end{tabular}

MRI, magnetic resonance imaging.

the course, cord swelling or enhancement may be seen, but later atrophy may be the only finding. ${ }^{29}$ Myokymia may be evident on electromyography (EMG) in affected muscles. MRI may show cord lesions indistinguishable from inflammatory lesions, but the simultaneous involvement of the adjacent vertebrae (usually hyperintense on T2-weighted scans) in the same field of radiation is an important clue to the etiology (Fig. 8).

\section{Paraneoplastic Disorders and Myelopathy}

When paraneoplastic antibodies are identified in neurological syndromes, they usually predict an underlying cancer and not necessarily a specific neurological syndrome. ${ }^{30}$ Several paraneoplastic antibodies are associated with subacute myelopathies, and a search for such antibodies and an underlying malignancy is
Table 10 Myelopathy Associated with Paraneoplastic Antibodies and Cancers

\begin{tabular}{|c|c|}
\hline $\begin{array}{l}\text { Cancers Associated } \\
\text { with Possible } \\
\text { Paraneoplastic } \\
\text { Myelopathies }\end{array}$ & $\begin{array}{l}\text { Paraneoplastic Antibodies } \\
\text { Associated with Myelopathies }\end{array}$ \\
\hline $\begin{array}{l}\text { Small cell lung } \\
\text { carcinoma }\end{array}$ & $\begin{array}{l}\text { Amphiphysin-lgG } \\
\text { CRMP-5 lgG } \\
\text { GAD } \\
\text { Cation channel antibodies* }\end{array}$ \\
\hline Breast cancer & PCA 2 \\
\hline Ovarian cancer & ANNA 2 \\
\hline $\begin{array}{l}\text { Non-small cell } \\
\text { lung cancer }\end{array}$ & $\begin{array}{l}\text { Neuronal and muscle AChR } \\
\text { antibodies }\end{array}$ \\
\hline
\end{tabular}

*P/Q or N-type calcium channel, KC voltage-gated potassium channel. Ig, immunoglobulin; CRMP, collapsin response-mediator protein; GAD, glutamic acid decarboxylase; PCA, Purkinje cell antibody; ANNA, antineuronal nuclear antibodies; AChR, acetylcholine receptor. 


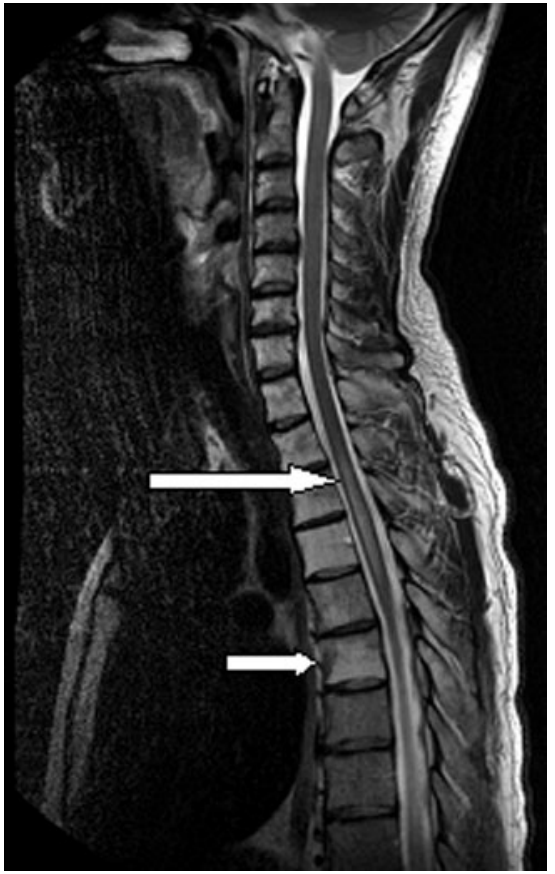

Figure 8 Radiation myelopathy. Sagittal T2-weighted image of the thoracic cord of a 34-year-old man with Hodgkin's lymphoma who received radiotherapy and presented 2 years later with subacute myelopathy and thoracic sensory level. Long arrow points to the longitudinally extensive T2 hyperintense intramedullary lesion. The short arrow points to the vertebral changes in the field of radiation. The vertebra immediately below seems normal. (Image courtesy of Dr Orhun Kantarci, Mayo Clinic, Rochester, MN.)

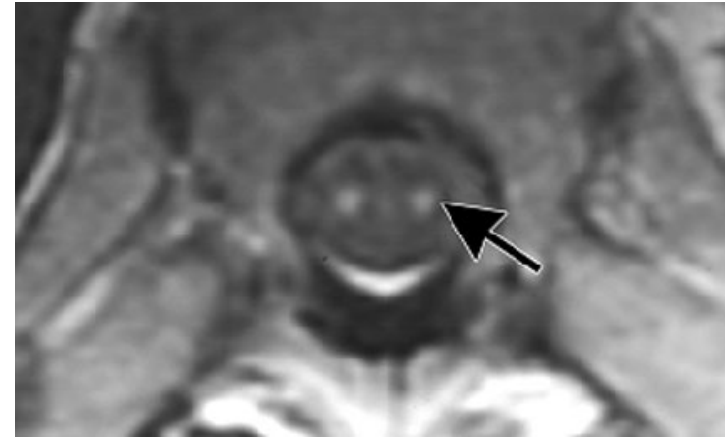

Figure 9 Paraneoplastic tractopathy. Axial T2 sections through the cord of a 69-year-old woman with melanoma and high titres of amphiphysin-immunoglobulin (lg)G. Arrow points to hyperintensity in the region of the corticospinal tracts. (Reproduced with permission from Pittock SJ, Lucchinetti CF, Parisi JE, et al. Amphiphysin autoimmunity: paraneoplastic accompaniments. Ann Neurol 2005;58[1]:96-107.)

warranted if other etiologies for the myelopathy are not apparent (Table 10). Autoimmunity to CRMP5 may lead to myelopathy and optic neuropathy that may mimic NMO, ${ }^{31}$ and when present, should spur a search for an underlying small cell lung carcinoma. Amphiphysin-specific antibodies raise the possibility of breast cancer. Detection of a longitudinally extensive tractspecific lesion, usually symmetrically involving both sides of the cord, may occur with diverse cancers. We have recently recognized this finding, particularly when accompanied by gadolinium enhancement, as a specific
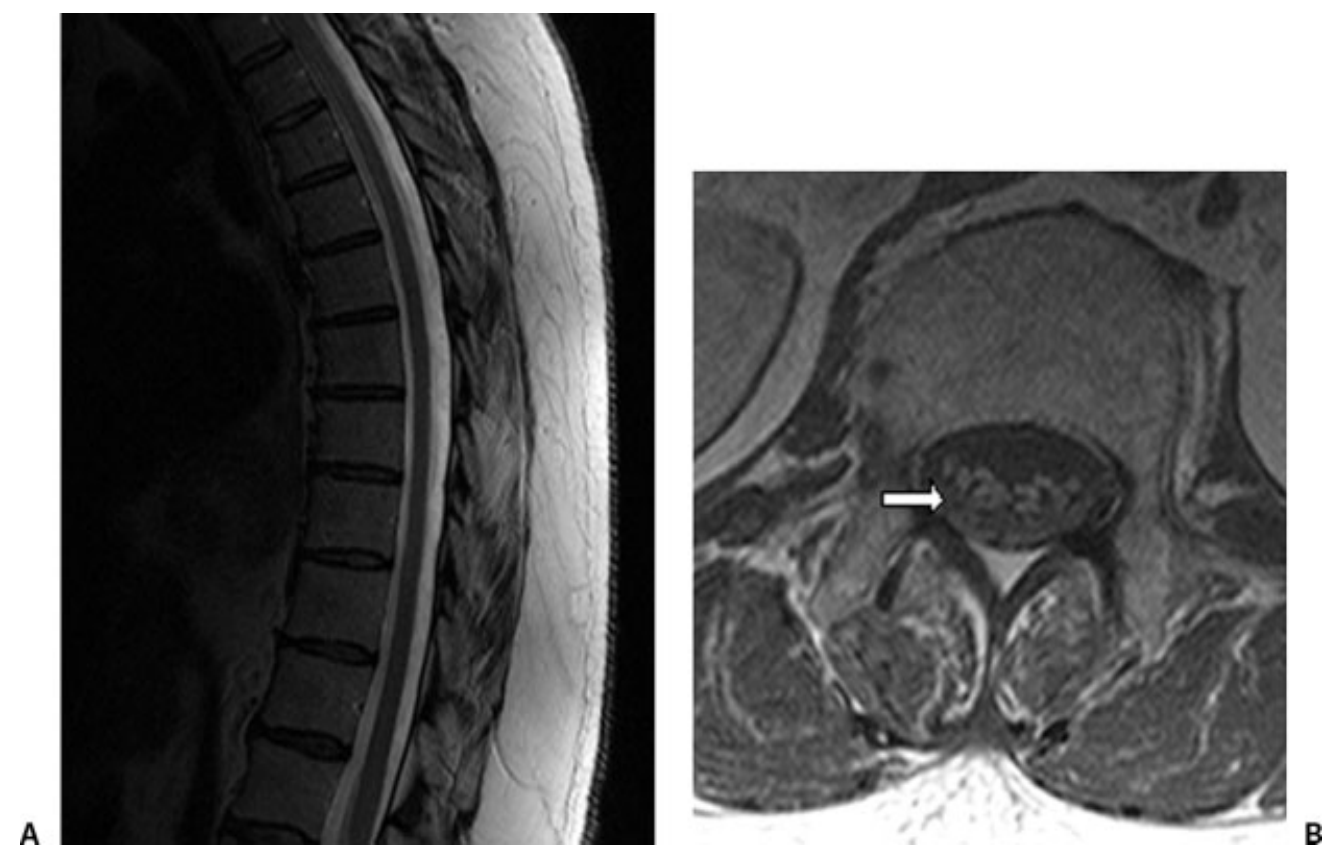

Figure 10 A 67-year-old woman with presumed acute myelopathy and markedly elevated cerebrospinal (CSF) protein. (A) T2weighted sagittal magnetic resonance imaging is normal; (B) T1-weighted, gadolinium-enhanced axial section through the cauda equina with gadolinium showed enhancing nerve roots. Nerve conduction studies confirmed acute inflammatory demyelinating polyneuropathy. 
radiological sign of a paraneoplastic myelopathy (Fig. 9). Some paraneoplastic conditions may mimic a myelopathy, although they are more likely "neurochemical" (e.g., GAD65 autoimmunity and stiff man syndrome-associated spasms may mimic spasticity; amphiphysin and rigidity/myoclonus may mimic spasticity). ${ }^{32-35}$

\section{Myelopathy with Normal Magnetic Resonance Imaging}

Occasionally, the MRI is normal in the setting of an acute myelopathy. There are several potential explanations. First, the syndrome may not be a myelopathy. Guillain-Barré syndrome may be mistaken as myelitis, especially considering the abnormal CSF protein concentration and ascending symptoms that may mimic those seen in myelitis. Enhancing nerve roots on MRI may be a clue to an inflammatory radiculopathy (Fig. 10). It is uncommon to find an acellular CSF in acute inflammatory myelitis. Second, it may not be an acute problem. It is well known that trivial trauma or environmental or physiological stressors like viral illnesses may decompensate a longstanding myelopathy, making it symptomatic to the patient. Friedreich's ataxia, motor neuron disease, vitamin $\mathrm{B}_{12}$ or copper deficiency myelopathy, hereditary spastic paraparesis, human immunodeficiency virus (HIV), human T-lymphotropic virus 1 (HTLV-1)-myelopathy, and adrenomyeloneuropathy may all have such "pseudo-acute" presentations. MRI scans are more often normal than not in these disorders.

Imaging performed during the convalescent phase may miss a cord lesion. The quality of the images may

Table 11 Approach to 'Myelopathy' with Normal Magnetic Resonance Imaging

\begin{tabular}{|c|c|}
\hline Alternative Explanations & Examples \\
\hline Has a compressive cause been missed? & $\begin{array}{l}\text { Epidural lipomatosis } \\
\text { Dynamic compression on flexion extension only }{ }^{46,47}\end{array}$ \\
\hline Is it really a myelopathy? & $\begin{array}{l}\text { Ganglionopathy, e.g., Sjögren's, paraneoplastic, toxins } \\
\text { Peripheral nerve disease, e.g., acute inflammatory } \\
\quad \text { polyradiculoneuropathy } \\
\text { Plexopathy, e.g., neoplastic or idiopathic inflammatory } \\
\text { Neuromuscular junction, e.g., myasthenia gravis } \\
\text { Muscle, e.g., periodic paralysis } \\
\text { Motor neuronopathy, e.g., ALS/primary lateral sclerosis }\end{array}$ \\
\hline Is there a cerebral cause for the deficit? & $\begin{array}{l}\text { Parasagittal meningioma } \\
\text { Cerebral venous thrombosis } \\
\text { Anterior cerebral artery thrombosis } \\
\text { Normal pressure hydrocephalus } \\
\text { Hydrocephalus } \\
\text { Small vessel disease (vascular lower limb predominant parkinsonism) } \\
\text { Other extrapyramidal disorders }\end{array}$ \\
\hline $\begin{array}{l}\text { Is it an acute presentation of an underlying } \\
\text { chronic metabolic, degenerative, } \\
\text { or infective myelopathy? }\end{array}$ & $\begin{array}{l}\text { B } 12, \text { folate, copper deficiency } \\
\text { Nitrous oxide inhalation } \\
\text { HTLV-1 } \\
\text { HIV } \\
\text { Syphilis } \\
\text { Motor neuron disease (ALS) } \\
\text { Adrenomyeloneuropathy } \\
\text { Hereditary spastic paraplegia } \\
\text { Friedreich's ataxia } \\
\text { Lathyrism }\end{array}$ \\
\hline Is the image quality adequate? & $\begin{array}{l}\text { Motion artifact } \\
\text { Low-strength magnet }(0.5 \mathrm{~T})\end{array}$ \\
\hline $\begin{array}{l}\text { Were the images taken too early or too late in time } \\
\text { and therefore "'missed"' the lesion (i.e., before } \\
\text { it appeared or after it resolved)? }\end{array}$ & $\begin{array}{l}\text { Long lesions of NMO may appear patchy } \\
\text { or short, and hence nondiagnostic, } \\
\text { if imaging is performed in the convalescent phase }\end{array}$ \\
\hline
\end{tabular}

Is the lesion too small to be seen on MRI?

Is the weakness not organic ("functional'")?

ALS, amyotrophic lateral sclerosis; HTLV-1, human T-lymphotropic virus 1; HIV, human immunodeficiency virus; NMO, neuromyelitis optica. 
have been suboptimal, especially in terms of resolution of an intramedullary lesion. Repeat imaging using sedation, if necessary, to prevent movement-related artifact may be needed if suspicion of myelopathy is high. Table 11 lists the various other possibilities for myelopathy with normal MRI.

\section{CONCLUSION}

Although inflammatory demyelinating etiologies account for a high proportion of acute myelopathies, other diagnoses need to be excluded. Once a demyelinating pathology is deemed likely, the chance of recurrence should be considered and, if appropriate, preventative treatments should be initiated. The proportion of idiopathic inflammatory myelitis is likely to decline with the increasing availability of newer autoimmune markers, imaging techniques, and microbiological tests capable of defining a specific etiology for an acute myelopathy.

\section{REFERENCES}

1. Pou Serradell A, Roquer Gonzalez J, Perich Alsina X. Acute posterior cord lesions in multiple sclerosis: an MRI study of the clinical course in 20 cases. Rev Neurol (Paris) 2000;156(12):1126-1135

2. Brex PA, Ciccarelli O, O'Riordan JI, et al. A longitudinal study of abnormalities on MRI and disability from multiple sclerosis. N Engl J Med 2002;346(3):158-164

3. Miller D, Barkhof F, Montalban X, Thompson A, Filippi M. Clinically isolated syndromes suggestive of multiple sclerosis, part I: natural history, pathogenesis, diagnosis, and prognosis. Lancet Neurol 2005;4(5):281-288

4. Fisniku LK, Brex P, Dan AR, et al. 20-year MRI and clinical follow-up of patients with clinically isolated syndromes suggestive of MS. Neurology 2007;68(suppl 1):A331

5. Lennon VA, Wingerchuk DM, Kryzer TJ, et al. A serum autoantibody marker of neuromyelitis optica: distinction from multiple sclerosis. Lancet 2004;364(9451):2106-2112

6. Weinshenker BG, Wingerchuk DM, Vukusic S, et al. Neuromyelitis optica IgG predicts relapse after longitudinally extensive transverse myelitis. Ann Neurol 2006;59(3):566569

7. Pittock SJ, Weinshenker BG, Lucchinetti CF, et al. Neuromyelitis optica brain lesions localized at sites of high aquaporin 4 expression. Arch Neurol 2006;63(7):964-968

8. Wingerchuk DM. Postinfectious encephalomyelitis. Curr Neurol Neurosci Rep 2003;3(3):256-264

9. Das RN, Jaykumar J. Acute transverse myelitis following typhoid vaccination. Ulster Med J 2007;76(1):39-40

10. Cizman M, Pokorn M, Osredkar D. Re: transverse myelitis after measles and rubella vaccination. J Paediatr Child Health 2005;41(8):460

11. Fonseca LF, Noce TR, Teixeira ML, Teixeira AL Jr, LanaPeixoto MA. Early-onset acute transverse myelitis following hepatitis $B$ vaccination and respiratory infection: case report. Arq Neuropsiquiatr 2003;61(2A):265-268

12. Booss J, Davis LE. Smallpox and smallpox vaccination: neurological implications. Neurology 2003;60(8):1241-1245
13. Larner AJ, Farmer SF. Myelopathy following influenza vaccination in inflammatory CNS disorder treated with chronic immunosuppression. Eur J Neurol 2000;7(6):731733

14. Ahasan HA, Chowdhury MA, Azhar MA, Rafiqueuddin AK. Neuroparalytic complications after anti-rabies vaccine (inactivated nervous tissue vaccine). Trop Doct 1995;25(2):94

15. Kaplin AI, Krishnan C, Deshpande DM, Pardo CA, Kerr DA. Diagnosis and management of acute myelopathies. Neurologist 2005;11(1):2-18

16. Krishnan C, Kerr DA. Idiopathic transverse myelitis. Arch Neurol 2005;62(6):1011-1013

17. Transverse Myelitis Consortium Working Group. Proposed diagnostic criteria and nosology of acute transverse myelitis. Neurology 2002;59(4):499-505

18. Hummers LK, Krishnan C, Casciola-Rosen L, et al. Recurrent transverse myelitis associates with anti-Ro (SSA) autoantibodies. Neurology 2004;62(1):147-149

19. Frohman EM, Havrdova E, Lublin F, et al. Most patients with multiple sclerosis or a clinically isolated demyelinating syndrome should be treated at the time of diagnosis. Arch Neurol 2006;63(4):614-619

20. Pittock SJ, Weinshenker BG, Noseworthy JH, et al. Not every patient with multiple sclerosis should be treated at time of diagnosis. Arch Neurol 2006;63(4):611-614

21. Villar LM, Masjuan J, Sadaba MC, et al. Early differential diagnosis of multiple sclerosis using a new oligoclonal band test. Arch Neurol 2005;62(4):574-577

22. Soderstrom M, Ya-Ping J, Hillert J, Link H. Optic neuritis: prognosis for multiple sclerosis from MRI, CSF, and HLA findings. Neurology 1998;50(3):708-714

23. Kincaid O, Lipton HL. Viral myelitis: an update. Curr Neurol Neurosci Rep 2006;6(6):469-474

24. Calgüneri M, Onat AM, Ozturk MA, et al. Transverse myelitis in a patient with Behcet's disease: favorable outcome with a combination of interferon-alpha. Clin Rheumatol 2005;24(1):64-66

25. Moskau S, Urbach H, Hartmann A, Schmidt S. Multifocal myelitis in Behçet's disease. Neurology 2003;60(3):517

26. Theodoridou A, Settas L. Demyelination in rheumatic diseases. J Neurol Neurosurg Psychiatry 2006;77(3):290295

27. Cheshire WP, Santos CC, Massey EW, Howard JF Jr. Spinal cord infarction: etiology and outcome. Neurology 1996;47(2):321-330

28. Jacob A, Das K, Boggild M, Buxton N. Inflammation or neoplasm? Another side to the story. Clin Neurol Neurosurg 2006;108(8):811-812

29. Wang PY, Shen WC, Jan JS. MR imaging in radiation myelopathy. AJNR Am J Neuroradiol 1992;13(4):10491055; discussion 1056-1048

30. Pittock SJ, Kryzer TJ, Lennon VA. Paraneoplastic antibodies coexist and predict cancer, not neurological syndrome. Ann Neurol 2004;56(5):715-719

31. Keegan M, Pittock S, Lennon V. Autoimmune myelopathy associated with CRMP-5 IgG. Mult Scler 2006;12(suppl 1): S24

32. Pittock SJ, Lucchinetti CF, Lennon VA. Anti-neuronal nuclear autoantibody type 2: paraneoplastic accompaniments. Ann Neurol 2003;53(5):580-587

33. Pittock SJ, Lucchinetti CF, Parisi JE, et al. Amphiphysin autoimmunity: paraneoplastic accompaniments. Ann Neurol 2005;58(1):96-107 
34. Pittock SJ, Yoshikawa H, Ahlskog JE, et al. Glutamic acid decarboxylase autoimmunity with brainstem, extrapyramidal, and spinal cord dysfunction. Mayo Clin Proc 2006;81(9): 1207-1214

35. Wingerchuk DM, Lennon VA, Pittock SJ, Lucchinetti CF, Weinshenker BG. Revised diagnostic criteria for neuromyelitis optica. Neurology 2006;66(10):1485-1489

36. Majid A, Galetta SL, Sweeney CJ, et al. Epstein-Barr virus myeloradiculitis and encephalomyeloradiculitis. Brain 2002; 125(Pt 1):159-165

37. Aktipi KM, Ravaglia S, Ceroni M, et al. Severe recurrent myelitis in patients with hepatitis $\mathrm{C}$ virus infection. Neurology 2007;68(6):468-469

38. Tan EM, Cohen AS, Fries JF, et al. The 1982 revised criteria for the classification of systemic lupus erythematosus. Arthritis Rheum 1982;25(11):1271-1277

39. Vitali C, Bombardieri S, Jonsson R, et al. Classification criteria for Sjogren's syndrome: a revised version of the European criteria proposed by the American-European Consensus Group. Ann Rheum Dis 2002;61(6):554-558

40. Alarcon-Segovia VM, ed. Classification and Diagnostic Criteria for Mixed Connective Tissue Disease. Amsterdam: Excerpta Medica; 1987

41. Preliminary criteria for the classification of systemic sclerosis (scleroderma). Subcommittee for scleroderma criteria of the
American Rheumatism Association Diagnostic and Therapeutic Criteria Committee. Arthritis Rheum 1980;23(5): $581-590$

42. Criteria for diagnosis of Behçet's disease. International Study Group for Behçet's Disease. Lancet 1990;335(8697):10781080

43. Weidauer S, Nichtweiss M, Lanfermann H, Zanella FE. Spinal cord infarction: MR imaging and clinical features in 16 cases. Neuroradiology 2002;44(10):851-857

44. Masson C, Pruvo JP, Meder JF, et al. Spinal cord infarction: clinical and magnetic resonance imaging findings and short term outcome. J Neurol Neurosurg Psychiatry 2004;75(10): 1431-1435

45. Han JJ, Massagli TL, Jaffe KM. Fibrocartilaginous embolism-an uncommon cause of spinal cord infarction: a case report and review of the literature. Arch Phys Med Rehabil 2004;85(1):153-157

46. Suzuki F, Nakajima M, Matsuda M. Cervical cord compression caused by a pillow in a postlaminectomy patient undergoing magnetic resonance imaging: case report. J Neurosurg 1999;90(suppl 1):145-147

47. Fujimoto Y, Oka S, Tanaka N, et al. Pathophysiology and treatment for cervical flexion myelopathy. Eur Spine J 2002; 11(3):276-285 